November a plant, it is said, started operation on an industrial scale in the Moscow coal area to supply gas for chemical manufacture. A new installation in the Donetz coal field is expected to dispense with the services of five hundred miners. Where oxygen is employed to enrich the blast and so produce a gas of higher calorific value and lower nitrogen content, the cost of the separation of oxygen from air largely determines the economics of the process. It is claimed that Prof. P. L. Kapitza has designed a plant for air separation which marks an advance in technical efficiency.

At a time like the present, it is important to picture the possible consequences of these developments. If successful, they would mean the reduction or abolition of one of the most arduous of human efforts, but only if coke could be dispensed. with. Coal, once gasified and converted into a mixture of carbon monoxide and hydrogen, becomes not merely a flexible source of heat and power, but also a starting point for the most diverse chemical syntheses. In a highly industrialized country like Great Britain, it would cause the grave problems of unemployment inevitable when remodelling the structure of industry. We need not be unduly timid about this because it will take a long time to surmount the technical and economic obstacles. It does, however, stimulate the spirit of curiosity and the will to look ahead which is often lacking in our old-established industries.

\section{Factory Lighting in Wartime}

IN the Engineering Supplement to the Siemens Magazine of February 1941, there is an instructive article by Mr. C. J. Misselbrook on "Factory Lighting in War Time". The fifth report of the Departmental Committee on Lighting in Factories issued in June 1940 has given a number of important recommendations on this subject and indicates a minimum standard which, although it would have been regarded a few years ago as unnecessarily lavish, is now in accordance with all good modern lighting practice. The recommendations of the report may be divided into two sections, adequacy and suitability, each of which presents its own problems. War conditions have resulted in the introduction of unskilled or semi-skilled workers into the industrial world and the work of training them is greatly facilitated if they are not expected to strain their eyes on unfamiliar tasks with inefficient lighting. In addition, the calling up of young men and their replacement by older workers increases the need for good lighting, for as a rule the eyes of older people are not so efficient as those of the younger generation, and consequently need more light for the equivalent 'seeing conditions'.

As regards adequacy, the report recommends a minimum illumination of six foot candles without prejudice to any additional illumination required by the nature of the work. This is a large increase on the one foot candle which was considered satisfactory when the last report was published about three years ago, but is easily obtainable with modern high- efficieney light sources. The question of providing illumination raises also the question of the amount of heat produced, which is sometimes excessive and gives rise to uncomfortable working conditions. The lighting specialist can often reduce the amount of heat by using an alternative type of lamp. For example, the 'Sieray' fluorescent tube is a good alternative to the 200-watt gas-filled lamp giving approximately the same amount of light but operating at a much lower temperature. There are many instances where the type and standard of work require a higher intensity of illumination than can normally be provided by general lighting. If this is provided by local lighting, all such points should be fitted with opaque shades, as an imperfectly screened lamp is a very frequent source of glare, leading to eye-strain and sometimes to accidents. With regard to wiring, the question arises when raising the standard of illumination, whether it is more economical to employ electric discharge lamps with their higher initial cost or to rewire the building. Sieray lamps have often proved of great value in such cases, as they can be readily interchanged with tungsten filament lamps with no alteration in the existing wiring.

\section{Royal Geographical Society Awards}

THE King has approved the award of the Royal Medals of the Royal Geographical Society as follows : Founder's Medal: Captain P. A. Clayton, for his surveys in the Libyan Desert and his application of this experience to desert warfare during recent operations ; Patron's Medal : Dr. Isaiah Bowman, president of Johns Hopkins University, Baltimore, for his travels in South America and for his great services to the science of geography while director of the American Geographical Society of New York. The Council of the Society has made the following awards : Murchison Grant: Mr. C. T. Madigan, for his explorations and research in Central Australia; Back Grant : Mr. Alfred Stephenson, for his surveys in south-east Greenland and in Graham Land; Cuthbert Peek Grant : Mr. Marcel Aurousseau, for his valuable services as secretary of the Permanent Committee on Geographical Names; Gill Memorial: Captain F. Spencer Chapman, for his exploration of high peaks in Sikkim and Tibet.

\section{Announcements}

Prof. W. W. C. Topley, F.R.S., professor of bacteriology and immunology in the University of London, has been appointed secretary of the Agricultural Research Council in succession to Sir Edwin. Butler, F.R.S., who has retired on account of ill. health.

ON April 8 an earthquake shock was felt in western Japan. Surface faulting took place, which damaged a railway track, causing goods trains to be derailed. No casualties have been reported. On April 9 a strong earthquake was felt at Terni in central Italy. This was followed by a strong aftershock. Neither shock caused damage. 